\title{
TRANSLATION AND VALIDATION OF THE CROATIAN VERSION OF THE MULTIDIMENSIONAL WORK MOTIVATION SCALE*
}

\author{
Eva Smokrović* \\ Maja Frencl Žvanut ${ }^{* * *}$ \\ Antun Bajan ${ }^{* * * *}$ \\ Radivoje Radic ${ }^{* * * * *}$ \\ Boštjan Žvanut ${ }^{* * * * *}$
}

Received: 12. 1. 2018

Preliminary communication

Accepted: 16. 4. 2018

UDC $005.32: 331.101 .3>303.2=163.42$

DOI https://doi.org/10.30924/mjcmi/2018.23.1.193

\begin{abstract}
In the contemporary working environment, it is important to have a referential instrument for assessing and comparing employee work motivation. Multidimensional Work Motivation Scale (MWMS) is a reliable and valid instrument for operationalising the Self-determination theory in practice (SDT). MWMS was previously translated into seven languages, and its validity and reliability were proved in nine different countries. The goal of this study was to translate it in Croatian and test its content and construct validity and reliability (internal consistency, item-total/interitem correlations and test-retest reliability) in
\end{abstract}

practice. The data was collected through a web survey. The final sample consisted of 141 participants. Our results confirm that the translated instrument is reliable and valid. The items of the translated instrumented loaded on the six factors as expected and showed a good fit to the basic factor structure. The translated version of MWMS could help the management in identifying potential problems related to motivation in Croatian companies.

Keywords: Self-determination theory, work motivation, questionnaire, validation, Croatian language

\footnotetext{
*We would like to thank: Marylène Gagné, BA McG., MA PhD Roch., School of Psychology, University of Western Australia for her consent and Tanja Paškvan for the review of the translated instrument and the proofreading of the manuscript. Finally, we would like to thank all the participants of the study. This manuscript is dedicated to our appreciated colleague, professor Radivoje Radić, PhD, who regrettably passed away on March 14, 2018.

** Eva Smokrović, MSc, Institute for Home health care and rehabilitation "Helena Smokrović", general manager and University of Rijeka, Faculty of Health Studies, Rijeka, Croatia.

${ }^{* * * *}$ Maja Frencl Žvanut, BSc, Čuječna soba, Koper, Slovenia.

${ }^{* * * * *}$ Antun Bajan, MSc, University of Osijek, Faculty of Medicine, Croatia.

${ }^{* * * * *}$ Radivoje Radić, PhD, University of Osijek, Faculty of Medicine, Croatia

****** Boštjan Žvanut, PhD, University of Primorska, Faculty of Health Sciences, Polje 42, SI-6310 Izola, Slovenia, Fax:+38656626480, e-mail: bostjan.zvanut@fvz.upr.si
} 


\section{Journal of Contemporary Management Issues}

\section{INTRODUCTION}

SDT is receiving increasing cross-cultural support in various domains such as health care (Ryan, Patrick, Deci \& Williams, 2008), education (Williams \& Deci, 1998), organisations and work (Gagné et al., 2010; 2014), sport (Myers, Martin, Ntoumanis, Celimli \& Bartholomew, 2014), and politics (Losier, Perreault, Koestner \& Vallerand, 2001). SDT, as a globally accepted theory of motivation, offers a valid multidimensional concept for the appraisal of the quality and level of motivation.

SDT is an empirically-based theory of human motivation, development and wellbeing. The theory is based on different types of motivation (i.e. autonomous motivation, controlled motivation, and amotivation), rather than just its amount in order to identify the motive for an individual's behaviour (Deci \& Ryan, 2008). Deci \& Ryan (2000) assume that human beings are inclined toward consolidation of their individual psychic elements into a unified sense of self and integration into more complex social systems. SDT can be applied to situations where intrinsic motivation is under consideration, e.g. in activities perceived by individuals as interesting, challenging or pleasing, but also to those where extrinsic motivation plays a prominent role, e.g. ordinary work activities (Tremblay, Blanchard, Taylor, Pelletier \& Villeneuve, 2009).

SDT clarifies the processes through which extrinsic motivation can become autonomous motivation (Gagné \& Deci, 2005), related to diverse positive outcomes. Indeed, in addition to intrinsic motivation, autonomous motivation also comprises specific types of extrinsic motivation whereby people have identified themselves with a particular value that is related to the activity they perform or, ideally, have even integrated this value in their sense of self (Deci \& Ryan, 2008). Autonomously motivated people experience a sense of self-endorsement when they successfully accomplish their actions. On the other hand, controlled motivation consists of both external and internal regulation. The mechanism of external regulation is based on external rewarding/punishing factors (e.g. financial reward, perks, penalties), which involves a certain amount of pressure on individual's behaviour. On the other hand, internal regulation is based on individuals' internal factors (e.g. confidence in own worth or abilities, self-respect, shame avoidance, ego-involvements). Both of them have an impact on an individual's intention, and thus behaviour, as opposed to amotivation, which represents a lack of motivation (Deci \& Ryan, 2008). Tremblay et al. (2009) emphasize that SDT self-determination axis, represented by amotivation at one extreme and intrinsic motivation on the other, does not reflect an individual's developmental continuum. In fact, each motivation element can increase/ decrease depending on different organisational factors or an individual's prior experiences or characteristics.

Previous research in this field showed substantial differences in autonomous vs. controlled motivation (Gagné \& Deci, 2005). While the former has a positive impact on work effectiveness and well-being, the latter can have a relevant negative impact on them, especially in situations when creative and intensive cognitive activities are performed (Gagné \& Deci, 2005). In order to find an optimal motivation balance, management should focus not only on employees' engagement and outcomes, but also on their subjective well-being in order to maximise their functioning (Gagné \& Forest, 2008).

In order to use SDT in the field of organisational behaviour, the MWMS was developed by Gagné et al. (2014). MWMS reliability and validity were confirmed by using the data obtained from 3435 employees in seven 
languages (in alphabetical order: Chinese, Dutch, English, French, German, Indonesian and Norwegian) coming from nine countries (Belgium, Canada, China, France, Indonesia, Norway, Senegal, Switzerland, and the United Kingdom). MWMS consists of 19 items representing 5 constructs: Amotivation (3 items: Am1-Am3), Extrinsic regulation - social (3 items: Ext-Soc1 - Ext-Soc3), Extrinsic regulation - material (3 items: ExtMat1 - Ext-Mat3), Introjected regulation (4 items: Introj1 - Introj4), and Identified regulation (3 items: Ident1 - Ident3). MWMS had the same factor structure and adequate convergent and discriminant validity tests across all the aforementioned seven languages and thus offers the opportunity for future research in this field in different socio-cultural contexts.

The search of literature showed that there was no formal translation of MWMS into the Croatian language, which was also confirmed by the leading author of the questionnaire. The goal of this study was to translate the MWMS into Croatian and test its validity and reliability in practice.

\section{METHODS}

\subsection{Translation procedure}

Three Croatian native speakers translated MWMS independently from English into Croatian. All three translated versions were consolidated in the final translated version, which was reviewed by an expert with considerable experience in translating texts from English to Croatian, and also by an expert in the field of psychology and human resource management. Subsequently, reverse translation was performed by a professional translator who did not participate in the previous translation. The reverse translation was consistent with the original questionnaire. All translators agreed that no special socio-cultural adaptation was required, which was later confirmed by six participants who tested the questionnaire for comprehensiveness (see subsection 3.2). In fact, according to the authors of the original MWMS, this instrument was designed to be culturally independent. The translated version of the instrument was further tested for validity and reliability, as described in the following sections.

\subsection{Participants}

The questionnaire was sent via email to 293 persons using the web based survey tool 1KA (University of Ljubljana 2016). The criteria for the inclusion in the study were as follows: the participants had to be Croatian native speakers, employed, had at least one year of working experience, and had their own email address. Substantial effort was put into finding the participants of various professions and industries. The web survey was available from 1 March to 12 April 2016, and non-respondents were reminded once, in the middle of this period. A total of 152 completed questionnaires were received, out of which 11 were excluded as they did not contain responses to all MWMS items. The final sample consisted of 141 participants (response rate $48.1 \%$ ): $78.7 \%$ female and $21.3 \%$ male. The age was normally distributed (skewness $=.25-$, kurtosis $=-.90$ ), the average age being 40.2 years $(S D=10.9)$. As for the level of education, one participant had completed only primary school, 27 (19.1\%) high school, 21 (14.9\%) two-year vocational college, $77(54.6 \%)$ had a bachelor's degree, and $15(10.6 \%)$ a master's or $\mathrm{PhD}$ degrees. The sample consisted of participants of various professions, employed in different work areas in private and public sectors. Approximately half of the participants $(48.2 \%)$ were health care staff (nurses: $32.6 \%$, physicians: $7.1 \%$, physiotherapists: $5.7 \%$, and other health care experts: $2.8 \%$ ); $22.7 \%$ were experts in the field of economy 
and management (administrators/clerks: 12.8\%; managers: 5.0\%; marketers/sellers $2.8 \% ; 2.1 \%$ were entrepreneurs); $10.6 \%$ experts in the field of research and education; $4.3 \%$ various profiles in legal sector; $3.6 \mathrm{em}$ ployed as psychologists, $10.6 \%$ of participants were individuals employed in different sectors (e.g. sport, social welfare), where only one or two participants form the same field were identified or the vocation reported in their responses was too general for including them in previously mentioned groups. Thus, it is a varied sample comparable to the Dutch one, reported in Gagné et al. (2014).

Fifty participants were randomly selected for the participation in the test-retest study. This number was determined by considering the minimum sample size requirements for computing Spearman correlation coefficient (Udovicic, Baždarić, Bilić-Zulle, Petrovečki, 2007).

\subsection{Statistical analysis}

Initially, descriptive statistics was performed, followed by analysis of construct validity, namely, principal component analysis with varimax rotation method. The cutoff value for displaying factor loadings was set to .4. Bartlett's Test of Sphericity between the items and Kayser-Meyer-Olkin test for sampling adequacy was used. Internal consistency was verified with the Cronbach's alpha coefficient. Multi-collinearity, interitem and corrected item-scale correlations were also investigated. Data analysis was performed with the statistical package IBM SPSS 22.0.

\subsection{Ethical considerations}

The author's consent for the translation was received by email on 27 May 2015. All participants were informed about the research aim and were asked to participate in the study. They had the right to withdraw from the study at any time without any consequences. No ethical approval was required for performing this study. The subjects' confidentiality was guaranteed both during and after the study, and in the testretest an anonymous code was used in order to keep the participants anonymous.

\section{RESULTS AND DISCUSSION}

This section presents the results of the reliability test (subsection 3.1) and the validity test of the translated instrument (subsection 3.2), followed by the study limitations and suggestions for further research (subsection 3.3).

\subsection{Reliability}

The results of internal consistency, itemtotal/inter-item correlations and test-retest reliability are presented in Table 1 . The overall Cronbach alpha was .81. Cronbach alpha coefficients of all constructs were above 0.7 , indicating that all constructs of the MWMS translated into the Croatian language are internally consistent. The lowest item-total correlation was .51 (item Am1). The inter-item correlations were all significant $(\mathrm{p}<.001)$, Spearman correlation coefficients ranged from .34 (between Introj1 and Introj4) to .87 (between Intrin2 and Intrin3). The results of the test-retest, which were performed on a smaller sample $(n=50)$, indicate that the participants' responses are consistent over time. All test-retest correlations were significant $(p<.001)$ for all corresponding pairs of pre- and post-test variables, the lowest value of Spearman correlation coefficient was .72 (item Ext-Soc2).

\subsection{Validity}

The two experts (see subsection 2.1) who revised the translation confirmed that the translation of MWMS into the Croatian language was valid and that the translated items clearly represented their respective constructs. Furthermore, six participants who tested the questionnaire 
Table 1: The results of the reliability tests of the MWMS in Croatian language

\begin{tabular}{|c|c|c|c|c|c|c|}
\hline 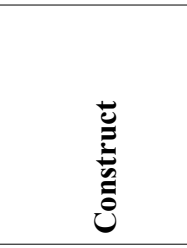 & 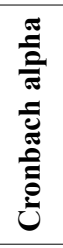 & $\Xi$ & 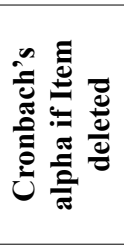 & 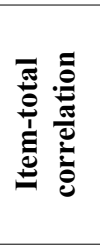 & 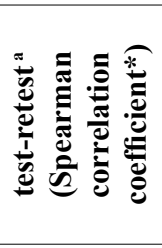 & 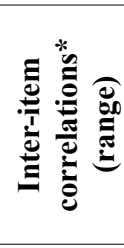 \\
\hline \multirow{3}{*}{ Amotivation } & \multirow{3}{*}{.81} & Am1 & .90 & .58 & 1.00 & \multirow{3}{*}[.80,.73]{} \\
\hline & & Am2 & .62 & .80 & .87 & \\
\hline & & Am3 & .72 & .70 & .80 & \\
\hline \multirow{3}{*}{$\begin{array}{l}\text { External } \\
\text { regulation } \\
\text { (Social) }\end{array}$} & \multirow{3}{*}{.91} & Ext-Soc1 & .90 & .77 & .75 & \multirow{3}{*}[.71,.76]{} \\
\hline & & Ext-Soc2 & .85 & .84 & .72 & \\
\hline & & Ext-Soc3 & .84 & .84 & .96 & \\
\hline \multirow{3}{*}{$\begin{array}{l}\text { External } \\
\text { regulation } \\
\text { (Material) }\end{array}$} & \multirow{3}{*}{.82} & Ext-Mat1 & .71 & .72 & .94 & \multirow{3}{*}[.56,.66]{} \\
\hline & & Ext-Mat2 & .75 & .68 & .91 & \\
\hline & & Ext-Mat3 & .80 & .63 & .85 & \\
\hline \multirow{4}{*}{$\begin{array}{l}\text { Introjected } \\
\text { regulation }\end{array}$} & \multirow{4}{*}{.83} & Introj1 & .80 & .61 & .94 & \multirow{4}{*}[.34,.74]{} \\
\hline & & Introj2 & .78 & .67 & .96 & \\
\hline & & Introj3 & .76 & .71 & .96 & \\
\hline & & Introj4 & .79 & .65 & .84 & \\
\hline \multirow{3}{*}{$\begin{array}{l}\text { Identified } \\
\text { regulation }\end{array}$} & \multirow{3}{*}{.93} & Ident1 & .89 & .87 & .94 & \multirow{3}{*}[.77,.80]{} \\
\hline & & Ident2 & .91 & .85 & .93 & \\
\hline & & Ident3 & .90 & .86 & .95 & \\
\hline \multirow{3}{*}{$\begin{array}{l}\text { Intrinsic } \\
\text { motivation }\end{array}$} & \multirow{3}{*}{.93} & Intrin 1 & .95 & .79 & .96 & \multirow{3}{*}[.76,.87]{} \\
\hline & & Intrin2 & .85 & .91 & .96 & \\
\hline & & Intrin3 & .88 & .87 & .97 & \\
\hline
\end{tabular}

$*_{p}<.001$ for all correlations

${ }^{a}$ computed on $n=50$

for comprehensiveness provided positive feedback.

Construct validity was tested with the factor analysis, the results of which are presented in Table 2. The results of Bartlett's test of sphericity $(p<.001)$ and Kaiser-MeyerOlkin Measure of Sampling Adequacy (.78) indicate that the sample data is suitable for factor analysis. The initial eigenvalues were $5.20,4.33,2.29,1.37,1.26$, and 0.97. The sixth factor with eigenvalue 0.97 was retained as it was close to 1 and the eigenvalue of the seventh factor was considerably lower
(0.67). These six factors accounted for $81.12 \%$ of the variance.

The translated MWMS items loaded on the six factors as expected and showed a good fit to the basic factor structure as in Gagné et al. (2014). Multicollinearity was identified only for two items: Intrin2 and Intrin3 cross-loaded with factor 1, which represents Identified motivation. As these loadings were lower than .5 , and the loadings of Intrin 2 and Intrin 3 on factor 4, which represents Intrinsic motivation, were respectively .84 and .82 , we can conclude that they 


\section{Table 2: Construct validity of the translated version of MWMS questionnaire in Croatian language $(n=141)$}

MWMS (English version)

Why do you or would you put effort into your current job?

\begin{tabular}{l} 
Construct \\
Items \\
\hline Amotivation \\
Am1: I don't, because I \\
really feel that I'm wasting \\
my time at work
\end{tabular}

Am2: I do little because I don't think this work is worth putting effort into.

Am3: I don't know why I'm doing this job. It's pointless work.

\section{Extrinsic regulation - social \\ Ext-Soc1:To get others' approval (e.g. supervisor, colleagues, family, clients...).}

Ext-Soc2:Because others will respect me more (e.g. supervisor, colleagues, family, clients...).

Ext-Soc3:To avoid being criticized by others (e.g. supervisor,colleagues, family, clients...).

\section{Extrinsic regulation - material}

Ext-Mat1: Because others will reward me financially only if I put enough effort into my job (e.g. employer, supervisor...).

Ext-Mat2: Because others offer me greater job security if I put enough effort into my job (e.g. employer, supervisor...).

Ext-Mat3: Because I risk losing my job if I don't put enough effort in it.

\section{Croatian translation}

Zašto ulažete ili biste uložili Factors (rotated solution)

trud u vaš trenutni posao?

$\begin{array}{lllllllll}\begin{array}{l}\text { Konstrukt } \\ \text { Čestice }\end{array} & 1 & 2 & 3 & 4 & 5 & 6\end{array}$

\section{Amotivativacija}

Am1:Ne ulažem ga, jer zaista imam osjećaj da tratim svoje vrijeme na poslu.

Am2:Radim malo jer smatram da u ovaj posao ne vrijedi ulagati truda.

Am3:Ne znam zašto radim ovaj posao. Besmislen je.

\section{Ekstrinzična regulacija- socijalna}

Ext-Soc1:Da bih dobio/la odobrenje drugih ljudi (npr. nadređenih, suradnika, obitelji, stranaka...).

Ext-Soc2:Zato jer će me drugi ljudi više poštovati (npr. nadređeni, suradnici, obitelj, stranke...).

Ext-Soc3:Da bi izbjegao/la kritike drugih ljudi (npr. nadređenih, suradnika, obitelji, stranke...).

\section{Ekstrinzična regulacija- materijalna}

Ext-Mat1: Zato jer će me financijski nagraditi samo ako uložim dovoljno truda u svoj posao (npr. poslodavac, nadređeni).

Ext-Mat2: Zato jer mi drugi ljudi nude veću poslovnu sigurnost ako uložim dovoljno truda u posao (npr. poslodavac, nadređeni).

Ext-Mat3: Zato što riskiram gubitak posla ukoliko ne uložim dovoljno truda u

6 


\begin{tabular}{|c|c|c|c|c|c|c|c|}
\hline Introjected regulation & Introjecirana regulacija & & & & & & \\
\hline $\begin{array}{l}\text { Introj1: Because I have to } \\
\text { prove to myself that I can. }\end{array}$ & $\begin{array}{l}\text { Introj1: Zato što moram sebi } \\
\text { dokazati da to mogu. }\end{array}$ & & 70 & & & & \\
\hline $\begin{array}{l}\text { Introj2: Because it makes } \\
\text { me feel proud of myself. }\end{array}$ & $\begin{array}{l}\text { Introj2: Zato jer se zbog } \\
\text { toga osjećam ponosnim/om } \\
\text { na sebe. }\end{array}$ & & 68 & & & & \\
\hline $\begin{array}{l}\text { Introj3: Because otherwise I } \\
\text { will feel ashamed of myself. }\end{array}$ & $\begin{array}{l}\text { Introj3: Zato što ću se u } \\
\text { suprotnome sramiti same/ } \\
\text { samoga sebe. }\end{array}$ & & 89 & & & & \\
\hline $\begin{array}{l}\text { Introj4: Because otherwise I } \\
\text { will feel bad about myself. }\end{array}$ & $\begin{array}{l}\text { Introj4: Zato što ću se u } \\
\text { suprotnome osjećati loše. }\end{array}$ & & 78 & & & & \\
\hline Identified regulation & Identificirana regulacija & & & & & & \\
\hline $\begin{array}{l}\text { Ident } 1 \text { :Because I personally } \\
\text { consider it important to put } \\
\text { effort into this job. }\end{array}$ & $\begin{array}{l}\text { Ident } 1: Z \text { ato što osobno } \\
\text { smatram važnim ulagati trud } \\
\text { u posao koji radim. }\end{array}$ & 83 & & & & & \\
\hline $\begin{array}{l}\text { Ident } 2 \text { :Because putting } \\
\text { effort into this job aligns } \\
\text { with my personal values }\end{array}$ & $\begin{array}{l}\text { Ident } 2 \text { :Zato što je ulaganje } \\
\text { truda u posao koji radim u } \\
\text { skladu s mojim osobnim } \\
\text { vrijednostima. }\end{array}$ & 89 & & & & & \\
\hline $\begin{array}{l}\text { Ident } 3 \text { :Because putting } \\
\text { effort into this job has } \\
\text { personal significance to me. }\end{array}$ & $\begin{array}{l}\text { Ident } 3: \text { Zato što ulaganje } \\
\text { truda u posao koji radim ima } \\
\text { osobno značenje za mene. }\end{array}$ & 85 & & & & & \\
\hline Intrinsic motivation & Intrinzična motivacija & & & & & & \\
\hline $\begin{array}{l}\text { Intrin1: Because I have fun } \\
\text { doing my job. }\end{array}$ & $\begin{array}{l}\text { Intrin1: Zato jer se } \\
\text { zabavljam radeći svoj posao. }\end{array}$ & & & & 92 & & \\
\hline $\begin{array}{l}\text { Intrin2: Because what I do in } \\
\text { my work is exciting. }\end{array}$ & $\begin{array}{l}\text { Intrin2: Zato što mi je } \\
\text { uzbudljivo ono što radim na } \\
\text { svom poslu. }\end{array}$ & 40 & & & 84 & & \\
\hline $\begin{array}{l}\text { Intrin3: Because the work I } \\
\text { do is interesting. }\end{array}$ & $\begin{array}{l}\text { Intrin3: Zato što je posao } \\
\text { koji radim zanimljiv. }\end{array}$ & 45 & & & 82 & & \\
\hline $\begin{array}{l}\text { Eigenvalues (rotated } \\
\text { solution) }\end{array}$ & & 2.84 & 2.64 & 2.63 & 2.56 & 2.38 & 2.36 \\
\hline $\begin{array}{l}\text { Total variance (\%) by } \\
\text { factors (rotated solution) }\end{array}$ & & 14.94 & 13.89 & 13.85 & 13.48 & 12.55 & 12.41 \\
\hline
\end{tabular}

do not represent a threat to the construct validity of the translated instrument. According to Tremblay et al. (2009), the types of motivation are aligned along a continuum, representing the degree of internalisation of individual goals and values: one extreme represents the amotivation, the other extreme represents the intrinsic motivation. Between these extremes the following types of regulations are lined up: external, introjected, identified, and integrated (Tremblay et al., 2009).
Identification, integration, and intrinsic motivation are the prototypes of self-determined motivations, whereas amotivation, external regulation, and introjection are categorized as non-self-determined motivations. The aforementioned two items of Intrinsic motivation cross-load with Identified motivation factor are probably due to their close position on the motivation continuum and the fact that both items represent Autonomous motivation. 
As expected, Introj2 loaded on factor 2, which represents the Introjected regulation. However, its loading was .68, which indicates a potential problem with the construct Introjected regulation as reported in Gagné et al. (2014).

\subsection{Study limitations and suggestions for further research}

Despite the fact that the reliability and validity of the MWMS in the Croatian language was tested on 141 participants only, the translated instrument proved to be reliable and valid. Although the research was performed on a statistically large enough convenient sample to perform the aforementioned statistical analyses, it is necessary to emphasize that the age, gender, education distribution and occupational variability of the final sample do not fully reflect the Croatian working population. Hence, further research should be conducted to additionally test the translated MWMS on a larger sample of Croatian native speakers, to completely ensure the conditions for the validation of the questionnaire in the Croatian speaking area. Both our results and those of Gagné et al. (2014) point to some minor problems with Introjected regulation. Hence, further studies should be performed to operationalise this construct. Despite the aforementioned limitations, the translated version can be used in the present form as a yardstick for operationalising the application of the SDT theory in the field of organizational behaviour in countries where Croatian language is spoken.

From the viewpoint of motivational theory, it is important to differentiate between types of motivation and use them in making predictions. MWMS represents an operationalisation of SDT grounded on the assessment of different motivation types. As such, it does not allow aggregating various types of motivation scores in the final score.
Hence, our suggestion for further research is directed toward further clarification of the work motivation process. In particular, it should focus on exploring the connections between the two main types of motivation and some established antecedents and important work outcomes, such as the need for autonomy, competence and relatedness (Gagne et. al 2014), emotional intelligence (Christie et al., 2007), life satisfaction (Diener et al., 1985), job satisfaction (e.g. Guntert, 2015), goal progress and plan implementation (Koestner et al., 2008), subjective well-being (Montasem, 2014) and perceived quality of working life (Šverko \& Galić, 2014).

\section{CONCLUSION}

This article presents the translated and validated version of the MWMS in Croatian language and thus contributes to the internationalisation of this instrument and proliferation of organisational research based on SDT. In the contemporary working environment, where multiculturality is a daily reality, it is important to have a referential instrument for assessing and comparing the employee work motivation. The translated instrument will help collect the data related to the implementation of SDT in the work context and identify potential problems related to motivation in organisations. We expect that the translated instrument will be broadly applicable to various business domains and that it will help in identifying individual differences related to motivation in organisational settings. 


\section{REFERENCES}

1. Deci, E. L., \& Ryan, R. M. (2000). The "what" and "why" of goal pursuits: Human needs and the self-determination of behavior. Psychological Inquiry, 11(4), 227-268.

2. Deci, E. L., \& Ryan, R. M. (2008). Selfdetermination theory: A macro theory of human motivation, development, and health. Canadian Psychology, 49(3), 182-185.

3. Diener, E., Emmons, R. A., Larsen R. J., \& Griffin S. (1985). The Satisfaction With Life Scale. Journal of Personality Assessment, 49(1), 71-75.

4. Gagné, M., \& Deci, E. L. (2005). Selfdetermination theory and work motivation, in: Journal of Organizational Behaviour, 26(4), 331-362.

5. Gagné, M. \& Forest, J. (2008). The study of compensation systems through the lens of self-determination theory: Reconciling 35 years of debate. Canadian Psychology, 49(3) 225-232.

6. Gagné, M., Forest, J., Gilbert, M.-H., Aubé, C., Morin, E., \& Malorni, A. (2010). The Motivation at Work Scale: Validation Evidence in Two Languages. Educational and Psychological Measurement, 70(4), 628-646.

7. Gagné, M., Forest, J., Vansteenkiste, M., Crevier-Braud, L., van den Broeck, A., Aspeli, A. K., Westbye, C. (2014). The Multidimensional Work Motivation Scale: Validation evidence in seven languages and nine countries. European Journal of Work and Organizational Psychology, 24(2), 178-196.

8. Güntert, S.T. (2015). The impact of work design, autonomy support, and strategy on employee outcomes: A differentiated perspective on self-determination at work. Motivation and Emotion, 39(1), 74-87.
9. Koestner, R., Otis, N., Powers, T. A., Pelletier, L., \& Gagnon, H. (2008). Autonomous Motivation, Controlled Motivation, and Goal Progress. Journal of Personality, 76(5), 1201-1230.

10. Losier, G. F., Perreault, S., Koestner, R., \& Vallerand, R. J. (2001). Examining individual differences in the internalization of political values: Validation of the Self-determination Scale of Political Motivation. Journal of Research in Personality, 35(1), 41-61.

11. Myers, N., Martin, J., Ntoumanis, N., Celimli, S., \& Bartholomew, K. J. (2014). Exploratory bi-factor analysis in sport, exercise, and performance psychology: A substantive-methodological synergy. Sport, Exercise, and Performance Psychology, 3(4), 258-272.

12. Montasem, A., Brown, S. L., \& Harris, R. (2014). Subjective well-being in dentists: the role of intrinsic aspirations. Community Dentistry and Oral Epidemiology, 42(3), 279-288.

13. Ryan, R. M., Patrick, H., Deci, E.L., \& Williams, G.C. (2008). Facilitating health behaviour change and its maintenance: Interventions based on selfdetermination theory. The European Health Psychologist, 10(1), 2-5.

14. Šverko, B., \& Galić, Z. (2014). The perceived quality of working life in Croatia and the European Union. Društvena Istraživanja: Journal for general social issues, 23(4), 557-575.

15. Tremblay, M.A., Blanchard, C. M.,Taylor, S., Pelletier, L. G., \& Villeneuve, M. (2009). Work Extrinsic and Intrinsic Motivation Scale: Its Value for Organizational Psychology Research. Canadian Journal of Behavioural Science, 41(4), 213-226.

16. Udovičić, M., Baždarić, K., Bilić-Zulle, L., \& Petrovečki (2007). What we need 


\section{Journal of Contemporary Management Issues}

to know when calculating the coefficient of correlation? (in Croatian: Što treba znati kada izračunavamo koeficijent korelacije?). Biochemical Medicine, 17(1), 10-15.

17. University of Ljubljana, Faculty of Social Sciences, Centre for Social
Informatics (2016, November 15). One Click Survey: Serious about data, Retrieved from http://english.1ka.si/.

18. Williams, G. C., \& Deci, E. L. (1998). The Importance of Supporting Autonomy in Medical Education. Annals of Internal Medicine, 129(4), 303-308.

\section{PRIJEVOD I VALIDACIJA HRVATSKE INAČICE MJERNE MULTIDIMENZIONALNE SKALE MOTIVACIJE ZA RAD}

\section{SAŽETAK}

U suvremenom radnom okruženju, značajno je posjedovati referentni instrument za evaluaciju i usporedbu radne motivacije zaposlenika. Multidimenzionalna skala motivacije za rad je pouzdan $i$ validan instrument za praktičnu operacionalizaciju teorije samo-određenja. Instrument je prethodno preveden na sedam jezika, a njegove su validnost $i$ pouzdanost dokazane u devet različitih država. Cilj ove studije je njegovo prevođenje na hrvatski jezik, kao i testiranje sadržaja te empirijsko testiranje validnosti i pouzdanosti (interne konzistencije, ukupnih korelacija i korelacija između čestica te pouzdanosti testiranja i ponovnog testiranja) njegovih konstrukata. Podaci su prikupljani putem internetskog upitnika. Konačni se uzorak sastojao od 141 sudionika. Dobiveni rezultati potvrđuju da je instrument pouzdan $i$ validan. Čestice prevedenog instrumenta čine šest empirijskih faktora, kao što je bilo i očekivano te dobro odgovaraju temeljnoj strukturi faktora. Inačica ovog instrumenta, prevedena na hrvatski jezik, može biti od pomoći menadžerima u identificiranju potencijalnih motivacijskih problema $u$ hrvatskim poduzećima. 